\title{
Analysis of the Development of IS (Islamic State) in Its Relation to Conflicts within OIC (Organization of Islam Countries) by Using SPSS Statistical Program
}

\author{
Seongju Oh, Chaeyun Jung, and Taeseon Yoon
}

\begin{abstract}
In this paper, the relationship between conflicts within OIC and historical development of Islamic state is studied in depth. By analyzing conflict databases that are divided into 4 periodical categories of Cold war and Decolonization, Post-Islamic Revolution, Fall of Berlin War and Soviet Empire, and Post 9/11 terrorism period, we found out the periodic phases significantly exacerbate the problem of Islamic diplomacy. We analyzed the intrinsic causes such as religion and corruption of Syria civil war and Iraq war to find out the reason for establishment of Islamic state, since IS primarily work in areas of Iraq and Syria. Through our statistical experiment, we showed that when both non-international armed conflicts (NIAC) and international armed conflicts (IAC) that involve states act in concert, the level of effective control a state has over its forces is the determining factor in whether the state can be said to be involved in an armed conflict. Using SPSS program, we calculated each frequency of conflicts that are divided into certain categories in order to show the broader perspective by using average $N$ standard deviation. By quantifying the amount of variation or dispersion of a set of data values, we proved the firm connection between conflicts with high standard deviation and its foundation for Islamic states, thereby proving that historical conflicts within Islamic countries set the reason for the formation of Islamic state and better strategy of diplomacy and its religious makeup is needed.
\end{abstract}

Index Terms-OIC (organization of Islam countries), IS (Islamic state), post-Islamic revolution, NIAC (Non-international armed conflict).

\section{INTRODUCTION}

Recently, the Muslim state is emerging as a region of conflict and violence for the reason of Islamic State (IS). The Islamic State (IS) is a radical Sunni Muslim organization whose aim is to restore an Islamic state or caliphate in the region encompassing Syria, Lebanon, Israel, Jordan, the Palestinian territories, and southeastern Turkey. In the words of US Secretary of Defense Chuck Hagel, "Islamic State (IS) is beyond anything we've seen." As a new form of terrorist group, Islamic State (IS) is penetrating deep into world and is threatening people. Most experts now believe that Islamic State (IS) has achieved successful financial self-sufficiency through a combination of extortion, old fashion pillaging, kidnapping and oil revenues and Islamic State (IS) has

Manuscript received May 26, 2015; revised August 30, 2015.

Chaeyun Jung and Seongju Oh are with the Hankuk Academy of Foreign Studies, Yonginsi, South Korea (e-mail: dbsco3923@hanmail.net, seongjuoh@gmail.com).

Taeseon Yoon was with Korea University, Seoul, South Korea. He is now with Hankuk Academy of Foreign Studies, Yonginsi, South Korea (e-mail: tsyoon@hafs.hs.kr). become the richest terrorist organization in history. With palpable gains and money on diverse sides, the group has captivated thousands of supporters from all around the world and is continuing to attract much more. Besides economic complete, Islamic State (IS) is really adroit at using the social media to spread propaganda and thus striking fear into the brains of public. For instance, on June 10, after Islamic State (IS) captured Mosul, its messages were spread towards the West. Most of the posts of Islamic State (IS) were still in Arabic but English tweets and translated videos flooded in just a few minutes as Islamic State (IS) targeted the Western audiences. One example clearly aimed to recruit young Westerners was the characters of two Islamic State (IS) fighters in the video game "Call of Duty'. "The big difference now is that Islamic State (IS) has its own English speakers," said Peter Neumann, Director of the International Center for the Study of Radicalization at King's College in London. "And it has its own media now where it can put this right out on Twitter and everybody can immediately see it and spread it online." Those strategies have increasingly been targeted directly at the global audiences. For another example, during the World Cup, Islamic State (IS) used a hashtag, \#WorldCup2014, attaining the massive soccer fans' attention to surge the Internet with its propaganda. It is obvious that Islamic State (IS) is one of the biggest cases of conflict, enough to go down in history.

However, the Muslim state has been the most controversial war-prone region from before the existence of Islamic State (IS). FrontPage Magazine published an article with the headline ' 8 Out of 10 Most Dangerous Countries in the World are Muslim' even before the Islamic State (IS) has influence like present. Actually, there have been lots of conflicts in Muslim state such as Iraqi-Kurdish conflict, Arab-Israeli conflict, Iran-Iraq war, and Syrian civil war with casualties over 100 thousands each other. It can be interpreted that this Islamic State (IS) case, the history that must never be repeated, is not any separate matter but a branch of Muslim State conflicts. So it will be helpful for prevention of these terrible conflicts to analyze tons of Muslim state conflicts and find some factors of the conflicts.

\section{RELATIVE RESEARCH}

\section{A. Syria Civil War}

Syrian civil war influenced by the movement for democracy in Middle East began with a small scale of peace protest. Tracing the history of Syrian antigovernment resistance, however, we can see that people's complaint 
about long-term seizure of power of Assad from 1971 had accrued. Alawi minority Muslim, which is about $12 \%$ of the population, had kept forceful government by training the military and Mukhabarat (the Arabic term meaning intelligence and often used by means of secret police) to oppress the Sunni majority Muslim and keep Alawi government.

Becoming the president in 2001, Bashar al-Assad tried the qualified reform policies. As the anxiety that excessive reformation might endanger the government spread over the leadership, however, some policies such as anti-corruption movement, release of political prisoners, economic liberalization, public political assembly and permission of freedom of the press eventually ceased.

People felt the gap between reality and ideals much more seriously because of their high expectation of the change, and now Syrian civil war begun with a demand for democratization has worsened due to the overreaching behaviors of Syrian government.

\section{B. Iraq War}

After 911terrorism happened in 2001, United States defined North Korea, Iraq and Iran as the axis of evil in January 2002. Then United States, on 20 March 2003, declared war by bombarding Southeast of Baghdad in order to protect not only its national safety but also the peace of the world by eliminating Iraqi production of weapons of mass destruction (WMD). The name of this plan was 'Freedom of Iraq'.

Starting the war, the allied forces stroke Iraqi missile base and information network system. The allied forces dominated Iraqi southeastern Basra on 22 March, and invaded Baghdad to destroy a presidential palace and a communications center. Also they dominated Saddam Hussein International Airport in Baghdad on 4 April, and invaded central Baghdad on 7 April, and finally United States perfectly seized Baghdad. As, on 14 April, United States invaded northern central Tigrite that was the last bastion as well as Hussein's hometown, the war actually ended. The conflict, however, continued for much of the next decade as an insurgency emerged to oppose the opposing forces and the post-invasion Iraqi government. The United States officially withdrew from the country in 2011.

\section{C. $\mathrm{OIC}$}

The use of OIC, Organization of Islam Countries, as the research topic has been considered previously a lot because it is the only international organization publicly stating "the collective voice of the Muslim World". The goal of this organization is to protect the interests of the Muslim world in the spirit of promoting international peace and harmony. Having permanent representations to the United Nations and the European Union, it has 57 members, 56 of which are member states of the United Nations [1]. As the world fear of Islamic terror increase, OIC adopted the OIC Convention on Combatting International Terrorism. The research about OIC had many fields of topics. For example, overview of the current developments in the OIC countries in the field of research \&development (R\&D) and science \& technology (S\&T) has been studied. In particular, the economic indicators of research and scientific development, Human Resources in R\&D, R\&D Expenditures, High Technology Exports, Scientific Publications, and Patent Applications are examined. Using knowledge and technology indices of the World Bank, the current status of OIC countries in comparison with the rest of the world in the scope of research and scientific development is analyzed. Specifically, joint research and investment on nanotechnology among the OIC member countries, networking opportunities in Framework programs, higher education and academic research through more government funds are suggested according to the result of the report [2]. Other interesting research about OIC was its Observatory on Islamophobia. The Report states that Islamophobia continues to manifest through different types of prejudice and discrimination against Muslims both as individuals and as a community. It produces the conclusion of the role of OIC that pluralism and diversity constitute an opportunity for cultures in open-minded attitude, respectfully interacting with, better understanding and enriching each other [3]. Other study analyzes the annual economic levels of the OIC countries since 1979 to serve as the basic background document for the comparison test of "World Economy and the Islamic Countries" The economic report examines the recent major economic improvements in the OIC countries and investigates the inter relationships with those in both developing and developed countries as well as the world economy as a whole [4]. Based on many academic researches on OIC countries, we focused on analyzing the types of conflicts between OIC countries in historical point of view.

\section{Cold War and IS}

Before we analyze the close affiliations of cold war and IS, several researches related to the international and global security in the post-cold war era are studied. To be specific, the cold war describes the relationship between United States and the Soviet Union 1945 to 1980.Neither side ever fought the other because the consequences would be too catastrophic. However, they fought for their beliefs using client states. It was to dominate international affairs for decades and many major crises such as Cuban missile crisis, Hungary and the Berlin wall occurred. A clash of different beliefs and ideology, capitalism and communism formed the basis of an international power struggle [5].

Cold War has inner relationship with the development of Islamic state. After the cold war, there had been mainly many conflicts such as Vietnamese war, China-Vietnam borderline war, Soviet union-Afghanistan invasion, collapse of USSR, re-unification of Germany and Ukraine affairs. Since the Ukraine affairs happen, economy of Russia collapsed. Because of this situation, Russia fortified the diplomatic military affairs in Middle East region to find the breakthrough. At first, Islamic state developed as a temporary phenomenon, extended version of corrupted anti-government military.

\section{E. Islamic Revolution}

The Islamic 1979 Revolution occurs after the overthrow of the Pahlavi dynasty under Mohammad Reza Shah Pahlavi, who was supported by the United States and replaced with the Islamic Republic under Ayatollah Ruhollah Khomeini, 
supported by Islamic organizations and Iranian student movements [6], [7].

The Revolution outbroke because of the Shah's policy of political liberalization. To denounce the government, secular opponents of the Shah, started to take action. After the death of Mostafa Khomeini, eldest son of Ruhollah Khomeini, the events began chronologically. Khomeini's political credentials gave political cast after the condolence of Mostafa. When strikes and demonstrations paralyzed the country, the shah left Iran for exile on January 16, 1979 and an opposition-based prime minister. Ayatollah Khomeini was invited back to Iran by the government and returned to Tehran to a greeting by several million Iranians [8].

\section{F. Fall of Berlin Wall and Soviet Empire}

The Revolution of 1989 was part of a revolutionary movement that resulted fall of communism in the Communist states of Central and Eastern Europe. Starting from Poland in 1989, the events continued in Hungary, East Germany, Bulgaria, Czechoslovakia, and Romania [9].

Though the Tiananmen Square protests of 1989 failed to instigate political changes in China, powerful symbolization of courage helped to precipitate the events in other parts of the globe. On the same day, the event that Solidarity won a significant victory in Poland leads to the fall of Communism rather peacefully in the summer of 1989. Through Hungary and destabilization of East Germany, Hungary disoriented the section of Iron Curtain causing a mass migration of East Germans. Eventually, these chains of events lead to city demonstrations like Leipzig and after that to the fall of the Berlin Wall, symbolic gate to German reunification in 1990 [10].

By the end of 1991, the Soviet Union was dissolved into 14 countries, Armenia, Azerbaijan, Belarus, Estonia, Georgia, Kazakhstan, Kyrgyzstan, Latvia, Lithuania, Moldova, Tajikistan, Turkm enistan, Ukraine, and Uzbekistan, stating their independence from Soviet Union. As several countries abandon its communism, eventually the collapse of Communism led commentators to declare the end of the Cold War [11].

\section{G. 9.11 Terror and IS}

9.11 terror was a series of four coordinated terrorist attacks by the Islamic terrorist group al-Qaeda on the United States in New York City, New York, and Arlington County, Virginia, on the morning of Tuesday, September 11, 2001. A lot of disastrous events happened on one day. Four passenger airliners from U.S East Coast to California were hijacked by 19 al-Qaeda terrorists to be flown into buildings in suicide attacks. Two of the planes, American Airlines Flight 11 and United Airlines Flight 175, were crashed into the North and South towers of the World Trade Center complex in New York City. A third plane, American Airlines Flight 77, was crashed into the Pentagon in Arlington County and the fourth plane, United Airlines Flight 93, was targeted at Washington D.C, but crashed into a field near Shanksville, Pennsylvania, after its passengers tried to overcome the hijackers [12]. New York confronted a disaster. The Twin Towers destruction and other properties caused serious impact on economy of Lower Manhattan and had a significant effect on global markets, closing Wall Street until September 17 and the civilian airspace in the U.S. and Canada until September 13. Al-Qaeda's motives for their attacks can be summarized into U.S. support of Israel, "attacks against Muslims" in Somalia, Support of Russian "atrocities against Muslims" in Chechnya, Indian "oppression against Muslims" in Kashmir, and the sanctions against Iraq [13].

After 9.11 terrors, it becomes evident that there is a significant increase among Islamic terrorist organizations overseas both on the Internet and phone lines. Several significant Islamic terrorist organizations like Al Qaeda and ISIS (Islamic state) have threatened the security of global community. Obama once confessed that current situation of U.S has not been prepared for a strategy yet for Islamic state. As it asserts its dominance on Iraq and Syria, Islamic State, like al Qaeda, has openly declared its intention on bringing terror to the interests of America around the globe. For example, the Islamic State executed American photojournalist James Foley on Aug. 19, and has used social media to threaten terror attacks on America.

\section{EXPERIMENT}

\section{A. Method}

For the experiment, we used the Muslim State Armed Conflict and Compliance (MSACC) Dataset: 1947-2014 Codebook. MSACC Dataset includes its Conflict Behavior, Compliance with International Humanitarian Law (IHL), Muslim Constitutions and Sharia Density and MSACC Conflict Chart. This Codebook describes our three meta-national datasets on self-identified Muslim states, defined by their membership in the Organization for Islamic Cooperation (OIC). Collectively termed the "Muslim State Armed Conflict and Compliance (MSACC) Datasets: 1947-2014," they include: (a) MSACC Dataset: Conflict Behavior; (b) MSACC Dataset: Compliance with International Humanitarian Law (IHL); and (c) MSACC Dataset: Muslim Constitutions and Sharia Density. MSACC Datasets Conflict Behavior and Compliance with IHL track the armed conflicts that each OIC member state has been involved in since 1947, and record instances of compliance and violation of International Humanitarian Law (IHL), respectively. MSACC Dataset: Muslim Constitutions and Sharia Density records the levels of Shari'a and International Human Rights Law (IHRL) content present in the constitutions of all OIC member states. Among these databases, we focused on analyzing conflict behavior. To define each term for the conflicts given by datasets, there are armed conflict, NIAC, IAC, ICTY and etc. For Armed Conflict, MSACC datasets utilize the international humanitarian law (IHL) definition of armed conflict is streamlined into two categories: non-international armed conflicts (NIAC) and international armed conflicts (IAC). ICTY represents the jurisprudence of the International Criminal Tribunal for the Former Yugoslavia. To be specific, NIAC, Non-International Armed Conflicts, is an armed conflict that takes place in the territory of a state between the armed forces of a state and dissident armed forces and other 
organized armed group. The conflict must meet a minimum threshold of intensity and the group must be sufficiently organized. For a group to be sufficiently organized, it must be able to carry out sustained and concerted military operations. On the other hand, International Armed Conflicts (IAC) is a resort to armed force between states and includes fights against colonial powers and alien occupation. In order to effectively determine whether Muslim state behave differently in conflict with other Muslim states or non-Muslim states, the datasets have added a subset to IACS, which is international armed conflicts between Muslim states(MM IAC). There are Incidents Not Considered Conflicts: Incidents between states and a non-state group such as internal disturbances and tensions, like riots, isolated and sporadic acts of violence, and other acts of a similar nature do not rise to the level of an armed conflict. Additionally, both NIACs and IACs have occasional issues related to violations and attribution to state parties [14].

We focused on analyzing conflicts within OIC countries in Conflicts summarized into 4 periodical phases: Cold war and Decolonization, Post-Islamic Revolution, Fall of Berlin War and Soviet Empire, and Post 9/11 terrorism period. We calculated the average $\mathrm{N}$ standard deviation in each category of conflicts that are mainly divided into periodic phases. For the statistical method, we mainly used SPSS program.
SPSS Statistics is a software package used for statistical analysis. Statistics included in the base software are largely divided into descriptive statistics, bivariate statistics, prediction for numerical outcomes, and prediction for identifying groups. Specifically, descriptive statistics involve cross tabulation, frequencies, descriptive, explore, and Descriptive Ratio Statistics. Bivariate statistics include means, t-test, ANOVA, Correlation (bivariate, partial, distances), and nonparametric tests. Prediction for numerical outcomes is linear regression. Prediction for identifying groups has factor analysis, cluster analysis (two-step, $\mathrm{K}$-means, hierarchical), and Discriminant.

\section{B. Progress}

Before running the statistical program, we aligned each data values in each column that effectively shows the periodical phases. After that we transformed the data values to binary to be aptly run into statistical program. Using SPSS program, we calculated each frequency of conflicts that are divided into certain categories in order to show the broader perspective by using average $\mathrm{N}$ standard deviation. By quantifying the amount of variation or dispersion of a set of data values, we tried to prove the firm connection between conflicts with high standard deviation and its foundation for Islamic states.

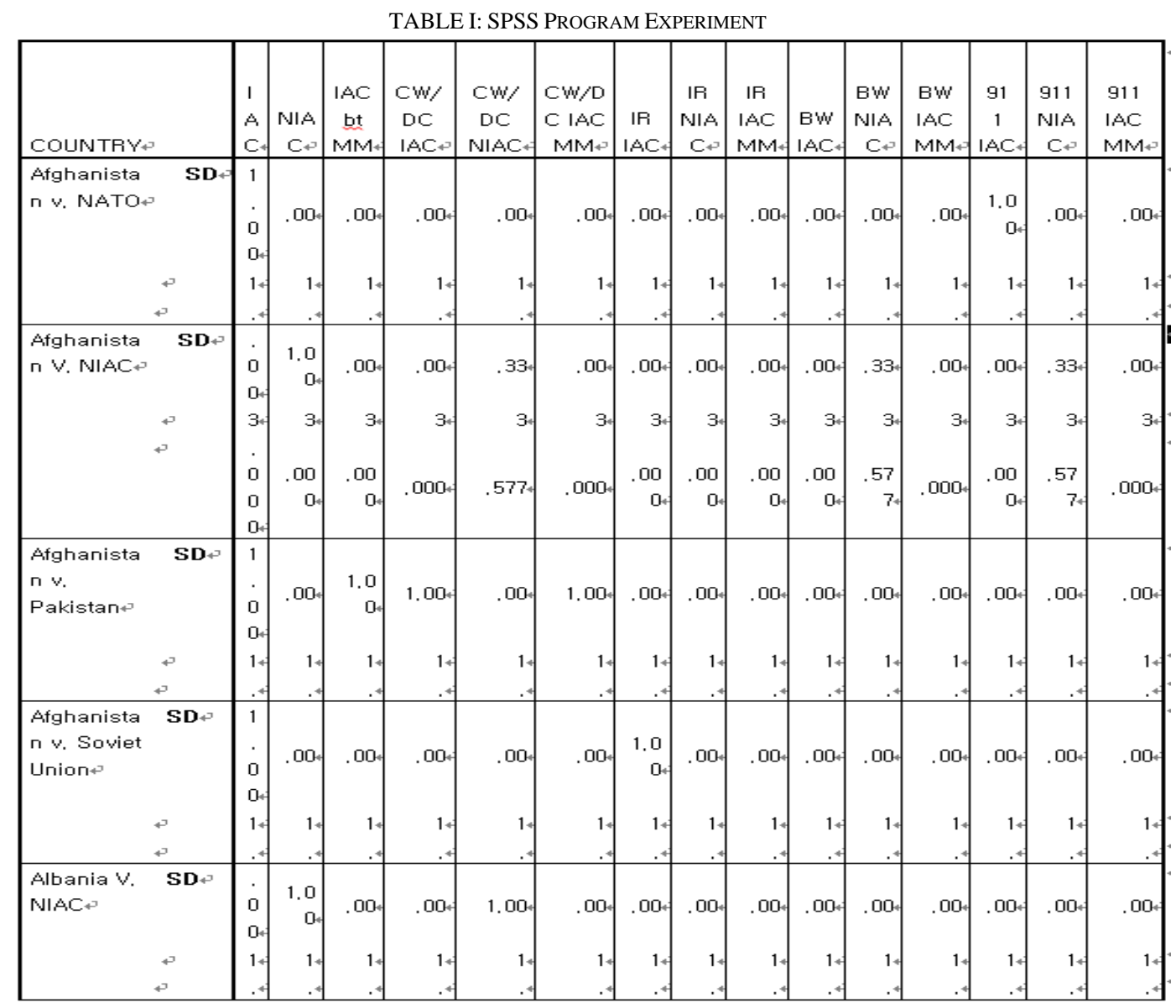

\section{Result}

Using SPSS program, we calculated each frequency of conflicts that are divided into certain categories according to the periods. It was different from country to country because the conflicting partner has disparate values. All the frequencies represented in the original dataset involve the internal relationship within two countries. Rather than highlighting the number, it was more educational to research its inner conflicts such as Gulf War and its impact. Looking 
at the frequencies, we thought the experiment would be much efficient when it turned to be standard deviation, analyzingthe value distant from the average. When the standard deviation is bigger, we took more care in analyzing the inner relationships because such conflict records have more possibility of developing the Islamic terrorist organization, Islamic state. Calculating the standard deviation provides different mathematical properties in expressing the variability of a population.

Looking at the table I, for example, country of Afghanistan with its non-international armed conflicts has its highest $\mathrm{N}$ average standard deviation. Therefore, we focused on researching NIAC of Afghanistan. By research, we extracted the information that in Saur Revolution, the Afghan military staged a coup in 1978, overthrowing Mohammad Daoud Khan and installing a communist government (PDPA) supported by the Soviet Union. The new government detained torture and executed rivals. Thousands of civilians were killed in Heart, Kerala, and other cities.

In Second NIAC, Civil war, and Taliban rule, after the Soviet withdrawal, President Mohammad Najibullah ruled Afghanistan. He was supported by the Soviets until the fall of his government in 1992. After the fall of the Najibullah government in 1992, Afghaninistan broke into civil war until 1996, when the Taliban controlled the government, 1996-2001, and implemented a strict brand of sharia on the nation. In Third NIAC, Taliban war, and al Qaeda, in June 2002, a transitional government was established. The conflict resumed between the Taliban and the government supported by the multinational coalition. Since 2002, Afghanistan has been a partnership with a U.S.-led coalition in the conflict against al Qaeda. In the first six months of 2010, almost 225 civilian deaths and 160 civilian injuries were caused by government forces, mostly by airstrikes. Afghan forces bomb enemy military facilities that are in civilian locations or within close proximity to civilian locations. By repeating the procedure of tracking out countries' conflicts with higher standard deviation, we found out inner relationships of those conflicts have rather stronger connection with Islam and its terrorism that in many cases, they provide the reason for development of Islamic states.

Our goal of statistical experiment was successful because we could see the broader perspective by using average $\mathrm{N}$ standard deviation. Proving the connection between conflicts with high standard deviation and its foundation for Islamic states was also accomplished. Therefore, we could stretch out the conclusion that historical conflicts within Islamic countries set the reason for the formation of Islamic state and better strategy of diplomacy and its religious makeup is needed.

\section{CONCLUSION}

In this paper as a whole, the connection between conflicts within OIC countries and development of Islamic state is proved in historical and scientific ways. First, by analyzing conflicts databases divided into 4 periodical categories of Cold war and Decolonization, Post-Islamic Revolution, Fall of Berlin War and Soviet Empire, and Post 9/11 terrorism period, we found out the historical background gives reason for the conflicts of OIC to occur. For example, after the cold war, there had been mainly many conflicts such as Vietnamese war, China-Vietnam borderline war, Soviet union-Afghanistan invasion, collapse of USSR, re-unification of Germany and Ukraine affairs.

Since Islam is badly known for Islamic state, though OIC or public Islam organization deny the roots of terrorist organization like Al-Queda and Islamic state, we thought there is strong connection in its historical roots of conflicts in the development of Islamic state. Because currently Islamic state has been working in the regions of Syria and Iraq, we try to analyze the intrinsic causes such as religion and corruption of Syria civil war and Iraq war. Back to the main point, we set our goal into analyzing the historical causes of Islamic state development with scientific method. Through using SPSS program of our statistical experiment, after looking at the frequencies described, we calculated each conflict's average $\mathrm{N}$ value standard deviation to track out complexity of conflicts tangled in Islam. Our expectation for the experiment was successful. The conflicts with bigger standard deviation with its more NIACS and IACS involved in its inner conflicts have more affiliations with the development of Islamic state historically. Through researching cases, we could see the broader perspective of the hidden crack that Islamic conflicts gave to the foundation for Islamic states. Thus, we can conclude that historical conflicts within Islamic countries set the reason for the formation of Islamic state and to prevent from more of such activism, better strategy of diplomacy and its strict toleration law of religious makeup in Islam as a whole are crucial.

\section{REFERENCES}

[1] OICUN. (March 2011). OIC convention on combating international terrorism. [Online]. Available: http://www.oicun.org/2/23/

[2] S. Alpay. (October 2009). Research and Scientific development in OIC countries. Statistical, Economic and Social Research and Training Centre for Islamic Countries (SESRIC), IMF, World Economic Outlook (WEO). [Online]. Available: http://www.sesrtcic.org/files/article/394.pdf

[3] B. Pitt. (June 2014). Islamophobia watch. [Online]. Available: http://www.islamophobiawatch.co.uk/

[4] S. Alpay. (December 2014). Enhancing productivity and competitiveness. Statistical, Economic and Social Research and Training Centre for Islamic Countries (SESRIC). [Online]. Available: http://www.sesrtcic.org/publications-detail.php?id=322

[5] R. McMahon, The Cold War: A very Short Introduction, Oxford University Press, 2003.

[6] C. Kurzman, "Structural opportunity and perceived opportunity in social-movement theory: The Iranina revolution of 1979," American Sociological Review, vol. 61, pp. 153-170, February 1996.

[7] H. Dabashi, Theology of Discontent, Iran: The Ideological Foundation of the Islamic Revolution, ISBN 9781412839723, Jan 1, 2010, pp. 121-123.

[8] R. Kahilli, A Time to Betray: The Astonishing Double Life of a CIA Agent Inside the Revolutionary Guards of Iran, New York: Simon and Schuster, 2010.

[9] A. Roberts. (1991). Civil Resistance in the East European and Soviet Revolutions. Albert Einstein Institution. [Online]. Available: http://www.aeinstein.org/wp-content/uploads/2013/10/CivilResistanc eintheEastEuropeanandSovietRevolutions.pdf

[10] R. K. Merton, On the Shoulders of Giants: The Post-Italianate Edition, University of Chicago Press, p. 348.

[11] W. Blum. (October 2014). The Berlin wall-Another Cold War myth. Foreign Policy Journal. [Online]. Available: http://www.foreignpolicyjournal.com/2014/10/20/the-berlin-wall-anot her-cold-war-myth/

[12] D. Caraley, September 11, Terrorist Attacks, and U.S. Foreign Policy, Academy of Political Science, 2002. 
[13] Institute for the Analysis of Global Security. (April 2014). How much did the September 11 terrorist attack cost America? [Online]. Available: http://www.iags.org/costof911.html

[14] Muslim State Armed Conflict and Compliance (MSACC) Dataset: 1947-2014, Codebook, [Online]. pp. 3-6. Available: http://insct.syr.edu/wp-content/uploads/2014/08/MSACC_Master_Co debook-080714.pdf

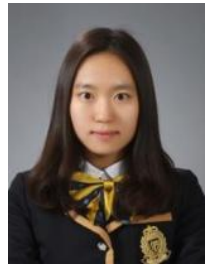

Chaeyun Jung was born in Korea, in 1997. She is a senior, twelfth grade student in the international program at Hankuk Academy of Foreign studies since 2014. She is the intern researcher of biological new medicine government institution lab, Dajeon and desalination-related Gookmin university lab in Seoul. She has attended the international conference on Engineering and Applied Science(ICEAS), held in Osaka, with the paper of 'Analyzing ECG segmentation and rule of patterns by using Viterbi algorithm (HMMs)' Many of her research papers has been published in the journal of ICCCE, IJBES and LNCS

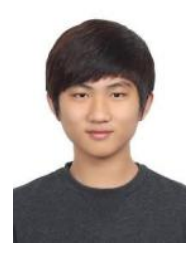

Seongju Oh was born in Korea, in 1997. He is an twelfth-grade student in the international program at Hankuk Academy of Foreign Studies.

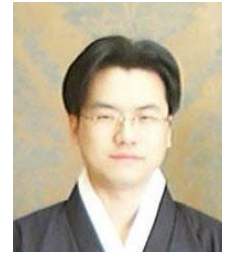

Taeseon Yoon was born in Seoul, Korea, in 1972. He was Ph.D. candidate degree in computer education from the Korea University, Seoul, Korea, in 2003. From 1998 to 2003, he was with EJB analyst and SCJP From 2003 to 2004, he joined the Department of Computer Education, University of Korea, as a lecturer and Ansan University, as a adjunct professor. Since December 2004, he has been with the Hankuk Academy of Foreign Studies, where he was a computer science and statistics teacher. He was the recipient of the Best Teacher Award of the Science Conference, Gyeonggi-do, Korea, 2013. 